for its extension in the countries of Eastern Europe and Ukraine, the definition of the connection of this legal institution with other elements of the legal system in Ukraine at that time. The problem is urgent and has a scientific and practical significance as an important historical form of local self-government.

In the scientific literature it is noted that just on the basis of the Magdeburg Law, medieval city self-government marked the beginning of the formation of local self-government in its modern sense and was its first historical form. The spread of the Magdeburg Law in the cities of Ukraine took place at a time when Ukraine was part of the Rzecz Pospolita. The basis of life in Kiev since the early 90's XV century by the end of the XVIII century Magdeburg Law, which determined the status of the city not only in the Grand Duchy of Lithuania and the Rzecz Pospolita, but also during the Hetmanate period under the direct authority of the Russian Empire. Despite the external influence, the extension of Magdeburg law in Ukrainian cities was facilitated by internal socio-economic and political factors.

The Magdeburg Law of Ukraine was part of the system of the law of Western Europe, which confirms the belonging of the legal system of Ukraine to the Roman-Germanic legal family. A number of socio-economic and political factors contributed to the expansion of Magdeburg Law in Ukrainian cities: accelerated development of agriculture, strengthening of the influence of commodity-money relations, which contributed to the elevation of Ukrainian cities and their inhabitants.

A conclusion is made about the significance of the Magdeburg Law in order to acquire the necessary historical experience and the basis for the development of local self-government in Ukraine, using the achievements of European countries.

Key words: local self-government, Magdeburg law, local authorities.

DOI: $10.33 .66 .3 / 2524-017 X-2019-10-111-115$

УДК 342.8; 324

\author{
Дарія Любомирівна Вімюк, \\ кандидат юридичних наук, дочент кафедри, \\ заступник завідувача кафедри теорії, \\ історії права і держави та конституиійного права \\ з наукової роботи ННІ права УДФСУ \\ Ольга Анатоліївна Павлюх, \\ старший викладач кафедри теорії, \\ історії права і держави та конституиійного права \\ ННІ права УДФСУ
}

\title{
ВИБОРИ ЯК ФОРМА БЕЗПОСЕРЕДНЬОЇ ДЕМОКРАТІЇ: ТЕОРЕТИКО-ПРАВОВИЙ АСПЕКТ
}

Постановка проблеми. Актуальність обраної теми дослідження полягає у тому, що вибори 3 найдавніших часів вважалися однією 3 найдієвіших та найефективніших форм безпосередньої демократії як в Україні, так і в інших державах. Стаття 69 Конституції України визначає, що «народне волевиявлення здійснюється через вибори, референдум та інші форми безпосередньої демократії» [1]. У сучасній науковій літературі з конституційного (державного) права популяризуються такі форми безпосередньої демократії як вибори, референдуми, відкликання, народна законодавча ініціатива, опитування населення, збори громадян тощо. Однак найбільша увага приділяється виборам як формі безпосередньої демократії, яка впливає на формування органів представницької демократії.

Вибори як форма безпосередньої демократії мають давню історію, сприяють реалізації народного суверенітету та $є$ показником рівня розвитку правової держави, громадянського суспільства, прав і свобод людини і громадянина тощо. Серед найяскравіших прикладів застосування виборів як важливої форми безпосередньої демократії з історії побудови української державності $є$ вибори Президента України, які відбулися 1 грудня 1991 р. одночасно з проведенням Всеукраїнського референдуму, який надав найвищої юридичної сили Акту проголошення незалежності України. Також це президентські вибори у листопаді - грудні 2004 року після Помаранчевої революції, яка була організована і проведена прихильниками Віктора Ющенка, та після Майдану 2014 року, який отримав назву «Революція Гідності» або «Євромайдан». Ці приклади застосування виборів 
при формуванні представницьких органів державної влади довели, що можна перетворити звичайне волевиявлення громадян України у волю українського народу. Практика проведення виборів в нашій державі на демократичних засадах та відповідно до чинного законодавства України присутня. Всі види виборів в Україні проводяться у визначений строк, але, зазвичай, супроводжуються певними проблемними моментами і тому виникає потреба у важливості узагальнення науковотеоретичної інформації та практичного досвіду застосування виборів як форми безпосередньої демократії при формуванні органів державної влади та місцевого самоврядування.

Аналіз останніх досліджень та публікацій. Формуванням представницьких органів державної влади та органів місцевого самоврядування за допомогою виборів як форми безпосередньої демократії у свої наукових працях цікавилися такі вітчизняні та зарубіжні вчені, як: М. Банковіч, Є. Ткачинські, Б. Банашак, І. Панкевич, М. Чудаков, М. Ставнійчук, К. Закоморна, О. Бориславська, І. Заєць, С. Різник, Л. Міхневич, О. Лапка, Т. Пікуля, Б. Страшун, М. Корнієнко, В. Маклаков, В. Погорілко, О. Лавринович, О. Скакун, В. Шаповал, В. Чіркін, В. Бесчастний, М. Горшеньов та інші. Однак, різноманітність наукових поглядів при дослідженні аспектів застосування виборів як форми безпосередньої демократії та сучасний стан розвитку демократії в Україні породжують нові підстави активізації наукового пізнання у даній сфері.

Мета статті. Визначити цінність виборів як форми безпосередньої демократії в умовах побудови незалежної, демократичної і правової держави. Також, застосовуючи комплексні підходи юридичної науки та призму правової аналітики, сформувати рекомендації щодо пріоритетних напрямів сучасного досконалого розвитку виборів та подальшого удосконалення їх застосування в Україні.

Основні результати дослідження. Необхідно наголосити на тому, що вибори є однією з основних форм безпосередньої участі громадян в управлінні справами держави і суспільства [2]. Вибори як важливе суспільне явище є способом формування представницьких органів та органів місцевого самоврядування [3]. Вибори також розглядаються як процес, унаслідок якого народ шляхом голосування формує склад державного органу чи обирає особу на виборну посаду [4]. Як правило, сформовані у результаті проведення виборів органи державної чи місцевої влади наділяються владними повноваженнями і отримують право діяти від імені народу, держави, територіальної громади і можуть приймати загальнообов' язкові рішення для виконання. Вибори - це процедура формування органів публічної влади, або надання повноваження посадовій особі, яке здійснюється шляхом голосування правомочних осіб за умови, що на кожен мандат який заміщується претендує декілька кандидатів [4]. Вибори можна розглядати як спосіб легітимації органів влади, тобто їх визнання та народної підтримки.

Краще усвідомити сутність виборів допоможе їх класифікація. За способом волевиявлення: прямі; непрямі. За кількісною ознакою: загальні; часткові. За територіальною ознакою: більшість вчених, а саме: В. Ріяка, В. Шаповал, В. Чіркін у свої працях зазначають поділ на: загальнонаціональні та місцеві, а у працях В. Бесчастного згадуються загальнонаціональні, місцеві та регіональні, наприклад, вибори у Канаді в межах провінції. За часом проведення: чергові; позачергові; нові - за умови, що вибори не відбулися або визнані недійсними; повторні - коли результат виборів не встановлюється після однократного голосування. Також, у В. Бесчастного існує ще класифікація в залежності від того, кого обирають, розрізняють парламентські, президентські та муніципальні вибори. Періодичність виборів залежить від терміну повноважень виборних органів та посадових осіб. Так, парламенти здійснюють повноваження протягом 4-5 років, наприклад, Верховна Рада України - 5 років, Національні збори Франції - на 5 років, Палата Представників в Японії- на 4 роки [5], а президенти - протягом 5-7 років. Так, президенти України, Німеччини, Франції, Болгарії, Індії обираються на 5 років, а президенти Молдови, Росії, Румунії, США обираються на 4 роки [5]. Іноді встановлюється обмеження на переобрання особи, як правило, не більше двох строків підряд, як в Україні, Німеччині, Чехії, Австрії, або переобрання не передбачається, як у Мексиці та Туреччині [5; 6, с. 31-32]. На періодичність виборів впливає і дострокове припинення повноважень і у такому випадку проводяться позачергові вибори [6, с. 32].

Важливо наголосити, що велике значення у реалізації виборів мають їх соціальні функції. Усі соціальні функції, які виконують вибори, активно впливають на життя особи, на процеси реалізації влади та визначають місце виборів у суспільно-політичному житті держави та особи. До таких функцій належать: 1) через вибори реалізується одне із найважливіших прав людини і громадянина - брати участь в управлінні державою, яке закріплене Загальною декларацією прав людини Генеральної 
Асамблеї ООН; 2) вибори є засобом забезпечення політичної влади через визнання їі населенням та готовність виконати будь-які розпорядження; 3) вибори як своєрідний барометр політичного життя визначають співвідношення різних політичних сил, інтересів, ідей у суспільстві і державі; 4) вибори слугують засобом відбору політичних лідерів, беручи до уваги відповідність якостей такої особи-лідера та міри довіри до неї особи-виборця; 5) одна з найважливіших функцій виборів вони $\epsilon$ важливим елементом забезпечення народного суверенітету та демократичного політичного режиму, тому що в основу даних правових явищ - воля народу та право народу на владу.

Загальновідомо, що вибори, в першу чергу, реалізуються через врегульовану нормами виборчого права діяльність різних суб' єктів щодо підготовки та проведення виборів, а саме: виборчий процес. Під поняттям «виборчий процес» розглядають врегульовану нормами виборчого права діяльність різних суб'єктів щодо підготовки та проведення виборів [4; 5; 6; 7]. У науці конституційного права можна умовно виділити такі стадії виборчого процесу:

1) призначення дати виборів - після закінчення повноважень виборчого органу або посадової особи дату зазначено у Конституції або інших відповідних законах, іноді право призначити вибори належить Главі держави, парламенту чи уряду (їх актом); як правило, день голосування - це неробочий день, а от у США - це вівторок; у Коста-Ріці вибори президента відбуваються раз на 4 роки у першу неділю лютого. Так само дата виборів призначається у Латвії, Мексиці, США [6, с. 30];

2) утворення виборчих округів - територіальних одиниць. від яких обирається один чи декілька депутатів. Округи бувають одномандатними, багатомандатними, загальнодержавними (у Конго до парламенту обирається єдина політична партія) або створюються для обрання деяких депутатів (як, наприклад, половини у Німеччині), інші ж обираються за одномандатними та багатомандатними округами;

3) утворення на округах виборчих дільниць - територіальних одиниць, які збігаються із державними утвореннями та обслуговуються одним пунктом для голосування, наприклад, у Франції виборчими дільницями $є$ комуни - найменші адміністративно-територіальні одиниці, в Італії комуни поділяються на виборчі дільниці по 100-800 виборців, в Україні, як правило, це підприємства, установи, організації державної форми власності;

4) утворення виборчих органів - до їх складу обираються певні посадові особи державного апарату чи уповноважені від політичних партій і ці органи бувають: територіальні; окружні; дільничні та можуть називатися: бюро, комісія, комітет тощо, а їх склад залежить від величини території, яку вони обслуговують та від кількості виборців, що проживають на ній;

5) реєстрація виборців та складання виборчих списків, формування виборчого корпусу чи з'ясування складу електорату, під яким розуміємо сукупність усіх виборців країни; в практиці відомі два види реєстрації: а) публічна (обов’язкова) - (ФРН, Швеція); б) особиста (добровільна) (США, Франція);

6) висунення кандидатів, яке може здійснюватися у вигляді: а) самовисування (Франція до палати представників); б) висунення політичними партіями, іншими громадськими об'єднаннями (ФРН, Австрія, у Данії потрібні підписи не менше ніж 25 виборців); в) петиційне (збір підписів за кандидата, Бельгія, Данія); г) первинні вибори у вигляді основного голосування - праймеріз (США) [5]. Цікавим є на цій стадії застосування виборчої застави як визначеної суми коштів, яка обов'язково вноситься особою до державного бюджету під час іiї реєстрації в якості кандидата на посаду президента;

7) передвиборча агітація, як не дивно, але це найбільш врегульована законодавством стадія законодавчого процесу, де чітко прописано форму проведення, дату, час проведення, кількість друкованих видань та інше. Ця стадія обумовлена важливими такими принципами, як рівність, законність, повага до честі та гідності свого опонента та інших. Вона, зазвичай, починається після реєстрації кандидатів або публікації їх списку (Литва), інколи - з дня оголошення дати голосування (Туреччина). Законодавчо передбачені умови агітації та іiі методи, початок і час припинення агітації, усі питання щодо використання засобів масової інформації, фінансування виборчої кампанії;

8) основною стадією виборчого процесу є голосування, яке, зазвичай, проходить протягом одного дня у визначені рамки часу, тобто завжди існує законодавче регулювання даної стадії, щоб забезпечити дійсно народне волевиявлення. Як правило, голосування може відбуватися такими способами: а) найчастіше за допомогою виборчих бюлетенів; б) за допомогою виборчих машин (США, Індія); в) за допомогою електронних карток (Бразилія, Балтика); г) поштою (ФРН, у Ве- 
ликій Британії, Німеччині, Данії цю форму використовують близько 10 \% виборців); д) за довіреністю (у випадках хвороби, закордонного відрядження, неписьменності та ін. (наприклад, у Франції, Великій Британії)) [2; 5].

9) заключною стадією виборчого процесу є підрахунок голосів та оголошення результатів виборів.

Отже, з вищевикладеного видно, що поділ стадій $є$ умовним, так як вони можуть поглинати одна одну, відбуватися одночасно або об'єднуватися. Одні стадії чітко законодавчо врегульовані, а інші - ще мають ряд проблем з цим. Тому є зрозумілим, що на кожній 3 них можуть відбуватися порушення, які обумовлені зловживаннями учасників та конфліктами між ними.

У теорії та практиці конституційного права часто взаємозамінними, тісно пов'язаними та взаємозалежними є поняття «вибори» та «виборче право». Тому аналіз виборів потребує детального розгляду поняття «виборчого права». У науці конституційного права поняття та сутність виборчого права як важливого елементу реалізації виборів розглядається у двох значеннях: 1) як об'єктивне виборче право та як суб'єктивне виборче право. Об'єктивне виборче право - це інститут безпосередньої демократії та інститут конституційного права, який формується із конституційних норм та інших правових норм і регулює порядок організації та проведення виборів. Джерелами об'єктивного виборчого права є: конституції, конституційне закони, органічні закони, регламенти парламенту, постанови урядів, укази глави держави). Так, у Швеції діє один акт - «Закон про вибори» 1972 р. У КНР прийнято кілька актів, які регулюють порядок проведення виборів до вищих і місцевих представницьких установ. Наприклад, ст. 10 Конституції Болгарії 1991 р. проголошує, що «вибори, загальнонаціональні та місцеві референдуми проводяться на основі загального, рівного і прямого виборчого права при таємному голосуванні». Такі самі принципи закріплені також у Конституції Франції. Частина 2 ст. 3 говорить, що голосування може бути прямим або непрямим відповідно до умов, передбачених законодавством, і що воно (голосування) завжди $€$ загальним, рівним і таємним. У тексті Конституції Португалії виділяється спеціальна ст. 116 «Загальні принципи виборчого права».

Щодо розгляду суб'єктивного виборчого права, то його основи закладені у ст. 71 Конституції України, де вказується, що вибори в Україні до органів державної влади та місцевого самоврядування $є$ вільними та відбуваються на основі загального, рівного і прямого виборчого права шляхом таємного голосування [1]. Усім виборцям гарантується вільне волевиявлення. Тому суб'єктивне виборче право - це, перш за все, право кожного із громадян стати учасником (суб'єктом) конституційно-правових відносин, що виникають при виборах, тобто здатність обирати і бути обраними. Таке відношення суб'єкта до виборчого процесу іменується у конституційному праві як активне виборче право та пасивне виборче право. Великий вплив на реалізацію громадянином свого активного чи пасивного права мають принципи виборчого права. Їх є надзвичайно багато, але зупинимося на основних або таких, які є важливими для особи і реалізації ії виборчого права.

Такими принципами є:

1) загальність виборчого права - у виборах беруть участь усі, за винятком неповнолітніх та недієздатних, тобто дорослі та психічно здорові громадяни. Даний принцип може обмежуватися певними цензами: а) цензом громадянства; б) віковим цензом, який є різним: наприклад, для активного виборчого права здебільшого з досягнення повноліття, наприклад, 18 р., а у Нікарагуа, Бразилії, Ірані - 16 р., у Марокко - 20 р., у США та Латвії - 21 р.; а для пасивного виборчого права - вимагається підвищеного віку особи, тобто наявності певного життєвого досвіду: для вирішення державних справ у Франції до нижньої палати - 23 роки, зазвичай 23-25 років; до верхньої палати - 40 р., зазвичай 30-40 років; Президенти США, України - 35 років, у Болгарії - 40 років, у КНР - 45 років, зазвичай 35 - 40 років; не був особою похилого віку [6, с. 32]; в) цензом осілості - загалом для виборчого права необхідно, щоб у суб'єкта виборчого процесу був наявний певний строк проживання у цій державі у певній місцевості; наприклад, у США активне виборче право визнається за особою, що проживає на території 1 міс., в Австралії, Німеччині, Японії - 3 міс., у Бельгії, Франції - 6 міс., у Канаді, Фінляндії - 12 міс., в Ісландії слід проживати не менше 5 років, у Норвегії, Україні для пасивного права - 10 років; у Грузії - 15 років $[6$, c. 32]; г) ценз мови - особливо актуальний для пасивного виборчого права (знання державної мови); г) майновий ценз - наявність у особи певної суми коштів (виборча застава для особи у кандидати на посаду президента); тощо.

2) свобода волевиявлення або принцип вільної участі у виборах - добровільна участь у виборах, контроль за волевиявленням громадян $€$ неприпустимим (є характерним для багатьох країн англо- 
саксонської правової системи та обов'язковим в Італії, Австрії, Греції, Туреччині). Однак, цей принцип може породити таке явище, як абсентеїзм - масове ухилення виборців від участі у виборах. Абсентеїзм можна розглядати з двох сторін: у першому випадку - це аполітична поведінка виборця через хворобу, віддаленість виборчої дільниці та відсутність зацікавленості у виборах; а у другому - політична поведінка спрямована на вираження протесту кандидатам та їхнім позиціям. Одним із шляхів подолання цього явища є обов'язковий вотум (висловлення думки), який у деяких країнах виражений через закріплений законодавчо обов'язок взяти участь у голосуванні та вибоpax. Абсентеїзм майже відсутній в Італії, де введено обов'язкове голосування (ст. 48 Конституції), в Австралії та Австрії, де встановлені відповідно адміністративна та кримінальна відповідальність за абсентеїзм. Це явище практично відсутнє у країнах тоталітарного політичного режиму з відомих причин (КНДР, Куба, В’єтнам, КНР, Лаос і т. ін.);

3) рівність виборчого права означає, що кожен громадянин має однакове число голосів в державі, голоси мають одинакову політичну вагу, існує єдиний виборчий корпус; депутат обирається від рівного числа жителів або виборців, а також закон містить одинакові вимоги до порядку висунення кандидатів, проведення виборчої компанії і визначення результатів виборів. Однак $є$ й поняття плюрального вотуму, за яким певні виборці мають більше голосів, ніж інші (власники нерухомого майна; ті, що мають вищу освіту), але воно є рідкістю у сучасних умовах проведення виборів;

4) принцип прямих виборів - обрання безпосередньо громадянами своїх представників в органи держави чи на окремі посади. Майже завжди прямими виборами обираються: депутати нижньої палати парламенту (США, Бельгії, Італії); однопалатні парламенти (України, Греції, Болгарії); органи місцевого самоврядування (Франції, Болгарії); президенти (Франції, Мексики, Єгипту, Болгарії);

5) принцип непрямих виборів - це коли вибори проводяться спеціально створеною для цього виборчою комісією чи колегією; постійно діючим органом; багатоступеневі вибори - низові представницькі органи обираються безпосередньо громадянами і в подальшому формують вищестоящі представницькі органи, а ті обирають вищу ланку; наприклад, у США президента обирають спеціально вибрані виборці;

6) принцип таємності голосування - право кожного заповнити виборчий бюлетень безконтрольно у спеціально створеній для цього кабіні чи кімнаті для голосування;

7) окрім того, до пасивного виборчого права відносять і несумісність та невиборність. Несумісність посад, мандатів має на меті дотримання принципу розподілу влади, гарантування виборцям свободи на виборах, заборону кандидатам зловживання своїм службовим становищем, забезпечення незалежності парламентаріїв. Невиборність передбачає спеціальні випадки неможливості балотуватися, перебуваючи на посаді.

Висновки. Отже, у статті розкрито взаємопов'язаність понять: вибори, виборче право, об'єктивне виборче право, суб'єктивне виборче право, активне виборче право, пасивне виборче право, виборчий процес та виборча система. Вдалося за допомогою класифікації виборів, характеристики функцій виборів, принципів виборчого права та стадій виборчого процесу визначити сутність виборів та їх роль в системі організації органів державної влади. Як в Україні, так і світі, безпосередня демократія - це складне та багатогранне явище. I тому, в умовах становлення сучасного конституціоналізму, в Україні вибори як інститут безпосередньої демократії отримали нові пріоритети та достатньо прогресивно розвиваються.

\section{Список використаних джерел}

1. Конституція України. Відомості Верховної Ради України (ВВР), 1996, № 30, ст. 141 [Електронний ресурс] Режим доступу : https://zakon.rada.gov.ua/laws/show/254к/96-вр\#n4392

2. Конституиійне (державне) право зарубіжних країн : уавч. посібник / В. М. Бесчастний, О. В. Філатов, В. М. Суботін, С. М. Пашков; за заг. ред. В. М. Бесчастного. - К., Знання, 2007. - 467 с. - Серія «Вища освіта ХХІ століття». - С. $120-147$.

3. Державне (конституційне) право зарубіжних країн (навчальні матеріали та схеми) : посіб. для підготовки для іспитів. - К. О. Закоморна. 2-ге видання, перероблене. - Х. : Право, 2016. - 280 с.

4. Конституиійне право зарубіжних держав : навчально-методичний посіб./ О. М. Бориславська, І. Я. Заєць, С. В. Різник. - К. : ІнЮре, 2015. -360 с.

5. Кириченко В. М. Порівняльне конституційне право: модульний курс [текст] : навчальний посіб. / В. М. Кириченко, О. М. Куракін. - К. : Центр учбової літератури, 2012. - 256 с. [Електронний ресурс] - Режим доступу : https://pidruchniki.com/1381011448852/pravo/poryadok_formuvannya_parlamentu_strok_yogo_povnovazhen 
6. Павлюх О. А. Роль президента як глави держави в організації державної влади: Україна і світ / О. А. Павлюх // Міжнародний юридичний вісник: актуальні проблеми сучасності (теорія та практика) УДФСУ. Серія: Право. Вип. № 3-4 (12-13), 2018 - С. 28-35.

7. Лапка О. Я., Пікуля Т. О. Конституційне (державне) право зарубіжних країн (у схемах) : навчальний посіб. К. : Атіка, 2008. - 216 с.; Конституційне право зарубіжних країн: академічний курс. Шаповал В. М. - К. : Юрінком Інтер, 2014. - 464 с.

8. Конституиіийне право зарубіжних країн : навч. посібник / М. С. Горшеньов, К. О. Закоморна, В. О. Ріяка та ін. - 2-е вид., допов. і перероб. - К. : Юрінком Інтер, 2004. - 544 с.

9. Міхневич Л. В. Конституційне право зарубіжних країн (загальна частина) : навч.-метод. посіб. для самост. вивч. дисцип. - Вид. 2-ге, без змін. - К. КНЕУ, 2006. - 164 с.

10. Сучасна правова енциклопедія / О. В. Зайчук, О. Л. Копиленко, Н. М. Оніщенко [та ін.]; за заг. ред. О. В. Зайчука ; Інститут законодавства Верховної Ради України. - К. : Юрінком Інтер, 2010. - 384 с.

11. Конституциионое (государственное) право зарубежных стран : в 4 т. Т. 1-2. Часть общая : учебник / Отв. ред. проф. Страшун Б. А. - 3-е изд. обнов. и дораб. - М. : Издательство БЕК, 2000.

12. Чиркин В. Е. Конституционное право зарубежных стран : учеб. - 3-е изд. перероб. и дополн. - М. : Юристь, 2003.

13. Панкевич I. М. Вибори як засіб легітимізації влади / I. М. Панкевич // Науковий вісник Чернівецького університету. - 2013. - Вип. 714. Правознавство. - c. 43-47 [Електронний ресурс]. - Режим доступу : lawreview.chnu. edu.ua/visnuku/st/714/7.pdf

14. Панкевич I. Інститут безпосередньої демократії та розвиток українського конституціоналізму / I. Панкевич // Вісник Львівського університету. Серія юридична. 2013. Вип. 58. - С. 95-102 [Електронний ресурс]. - Режим доступу:file://C:/Users/Olya/AppData/Local/Packages/Microsoft.MicrosoftEdge_8wekyb3d8bbwe/TempState/ Downloads/Vlnu_yu_2013_58_15\%20(1).pdf

\section{References}

1. Konstytutsiia Ukrainy. Vidomosti Verkhovnoi Rady Ukrainy (VVR), 1996, № 30, st. 141. [Elektronnyi resurs] Rezhym dostupu : https://zakon.rada.gov.ua/laws/show/254k/96-vr\#n4392

2. Konstytutsiine (derzhavne) pravo zarubizhnykh krain: Navch. posibnyk / V. M. Beschastnyi, O. V. Filatov, V. M. Subotin, S.M. Pashkov; za zah. red. V.M. Beschastnoho. - K., Znannia, 2007. - 467 s. - Seriia «Vyshcha osvita KhKhI stolittia». - S. 120-147.

3. Derzhavne (konstytutsiine) pravo zarubizhnykh krain. (Navchalni materialy ta skhemy): Posibnyk dlia pidhotovky dlia ispytiv. K. O. Zakomorna. 2-he vydannia, pereroblene. - Kh. : Pravo, 2016. - $280 \mathrm{~s}$.

4. Konstytutsiine pravo zarubizhnykh derzhav: navchalno-metodychnyi posib./ O. M. Boryslavska, I. Ia. Zaiets, S. V. Riznyk. - K. : InIure, 2015. - 360 s.

5. Kyrychenko V. M. Porivnialne konstytutsiine pravo: modulnyi kurs [tekst] : navchalnyi posibnyk / V. M. Kyrychenko, O. M. Kurakin. - K. : Tsentr uchbovoi literatury, 2012. - 256 s. [Elektronnyi resurs]. - Rezhym dostupu : https:// pidruchniki.com/1381011448852/pravo/poryadok_formuvannya_parlamentu_strok_yogo_povnovazhen

6. Pavliukh O. A. Rol prezydenta yak hlavy derzhavy v orhanizatsii derzhavnoi vlady: Ukraina i svit / O. A. Pavliukh // Mizhnarodnyi yurydychnyi visnyk: aktualni problemy suchasnosti (teoriia ta praktyka) UDFSU. Seriia: Pravo. Vypusk № 3-4 (12-13), 2018 - S. 28-35.

7. Lapka O. Ia., Pikulia T. O. Konstytutsiine (derzhavne) pravo zarubizhnykh krain (u skhemakh): Navchalnyi posibnyk. K.: Atika, 2008. - 216 s. Konstytutsiine pravo zarubizhnykh krain: akademichnyi kurs. Shapoval V. M. K. : Yurinkom Inter, 2014. - $464 \mathrm{~s}$.

8. Konstytutsiine pravo zarubizhnykh krain: navch.posibnyk / M. S. Horshenov, K. O. Zakomorna, V. O. Riiaka ta in. 2-e vyd., dopov. i pererob. - K. : Yurinkom Inter, 2004. - 544 s.

9. Mikhnevych L. V. Konstytutsiine pravo zarubizhnykh krain (zahalna chastyna) : navch.-metod. Posibnyk dlia samost. vyvch. dystsyp. - Vyd. 2-he, bez zmin. - K., KNEU, 2006. - 164 s.

10. Suchasna pravova entsyklopediia / O. V. Zaichuk, O. L. Kopylenko, N. M. Onishchenko [ta in.]; za zah. red. O. V. Zaichuka ; Instytut zakonodavstva Verkhovnoi Rady Ukrainy. - K. : Yurinkom Inter, 2010. - 384 s.

11. Konstytutsyonnoe ( hosudarstvennoe ) pravo zarubezhnykh stran: v 4 t. T. 1-2. Chast obshchaia : uchebnyk / Otv. red. prof. Strashun B.A. - 3-e yzd. obnov. y dorab. - M .: Yzdatelstvo BEK, 2000.

12. Chyrkyn V. E. Konstytutsyonnoe pravo zarubezhnыkh stran : uchebnyk. - 3-e yzd. pererob. y dopoln. - M. : Yuryst, 2003.

13. Pankevych I. M. Vybory yak zasib lehitymizatsii vlady / I. M. Pankevych // Naukovyi visnyk Chernivetskoho universytetu. - 2013. - Vypusk 714. Pravoznavstvo. - S. 43-47 [Elektronnyi resurs] - Rezhym dostupu : lawreview. chnu.edu.ua/visnuku/st/714/7.pdf

14. Pankevych I. Instytut bezposeredn'oyi demokratiyi ta rozvytok ukrayins'koho konstytutsionalizmu / I. Pankevych // Visnyk L'vivs'koho universytetu. Seriya yurydychna. 2013. Vyp. 58. - S. 95-102 [Elektronnyy resurs]. - Rezhym dostupu : file://C:/Users/Olya/AppData/Local/Packages/Microsoft.MicrosoftEdge_8wekyb3d8bbwe/TempState/Downloads/ Vlnu_yu_2013_58_15\%20(1).pdf 
Вітюк Д. Л., Павлюх О. А. Вибори як форма безпосередньої демократії: теоретико-правовий аспект

Актуальність обраної теми дослідження полягає у тому, що вибори - найефективніша форма безпосередньої демократії як в Україні, так і в інших державах.

У статті досліджується поняття виборів та соціальні функції виборів. Визначено критерії поділу виборів та охарактеризовано види виборів. Розкрито поняття «виборче право» та визначено його роль у контексті проведення виборів для формування органів державної влади. Висока суспільна-політична цінність виборів проявляється у характеристиці основних принципів виборчого права. Шляхом розгляду принципу загальності виборчого права підтверджено доцільність застосування виборчих цензів під час виборів. Розкрито поняття «виборчий процес» та охарактеризовано стадії виборчого процесу. Досліджено компетенцію органів, які обслуговують виборчий процес.

Стаття сприяє формуванню фундаментальних знань про функціонування виборів в Україні та зарубіжних країнах. Шляхом аналізу практики світового досвіду реалізації виборчого права під час виборів проведено прогнозування перспектив організації державної влади в Україні.

Ключові слова: вибори, форма безпосередньої демократії, абсентеїзм, виборче право, активне виборче право, пасивне виборче право, виборчий процес, виборча система.

Vityuk D. L., Pavlyukh O. A. Elections as a Form of Direct Democracy: the Theoretical and Legal Aspect

The relevance of a subject of a research is that elections an effective form of direct democracy both in Ukraine, and in other states.

In article the concept of elections and social functions of elections is investigated. Criteria of division of elections are defined and types of elections are characterized. The concept «electoral right» is opened and its role in the context of elections for formation of public authorities is defined. High social political value of elections is shown in characteristic of the basic principles of an electoral right. By consideration of the principle of generality of an electoral right the expediency of use of voting qualifications on elections is confirmed. The concept «selective process» is opened and stages of electoral process are characterized. The competence of the bodies serving electoral process is investigated.

Article promotes formation of fundamental knowledge of functioning of elections in Ukraine and foreign countries. By the analysis of practice of international experience of realization of an electoral right on elections forecasting of prospects of the organization of the government in Ukraine is carried out.

Key words: elections, form of direct democracy, absenteeism, suffrage, active suffrage, passive electoral right, electoral process, electoral system.

DOI: 10.33.66.3/2524-017X-2019-10-115-121

УДК 340.12; 321.01

Оксана Федорівна Данич, аспірантка відділу теорії держави і права Інституту держсави і права ім. В.М. Корецьккого НАН України

\section{ДО ПИТАННЯ ПРО РОЛЬ ПРАВОВОЇ СИСТЕМИ У ЗАБЕЗПЕЧЕННІ СОЦІАЛЬНОӤ ФУНКЦЇ̈ ДЕРЖАВИ: ГЛОБАЛІЗАЦІЙНИЙ ВИМІР}

Постановка проблеми. Однією з необхідних складових ефективного функціонування суспільства і держави, беззаперечно, є розвинена національна правова система з ії класичним центральним елементом - правом. В сучасних умовах саме праву та правовій системі належить особливе, самостійне місце серед інших соціальних явищ, оскільки на правову систему покладається основний тягар нормативного регулювання різноманітних суспільних відносин, забезпечення індивідуальних, групових та загальних (національних, державних) інтересів, а також вирішення виникаючих у суспільстві соціальних конфліктів. При цьому особливу роль правова система відіграє у забезпеченні нормативної регламентації різноманітних глобалізаційних процесів, у тому числі тих, які пов'язані з проблемами реалізації соціальної функції сучасних держав в умовах посилення «полярних» тенденцій розвитку соціальних відносин. 